\title{
ANALYSIS OF THE INFLUENCE OF KNOWLEDGE, RELIGIOSITY OF BRAND AMBASSADORS, SUBJECTIVE NORMS, PRODUCT QUALITY, AND ADVERTISING ON REPURCHASE INTENTIONS THROUGH ATTITUDES TOWARDS HALAL COSMETICS PRODUCTS WARDAH COSMETICS CUSTOMERS IN SURABAYA
}

\author{
Arlintya Yustica Fanny \\ Master of Management, Economy Faculty, Peita Harapan University, \\ Jl Ahmad Yani, Dukuh Menanggal, Surabaya
}

DOI: 10.46609/IJSSER.2020.v05i01.003 URL: https://doi.org/10.46609/IJSSER.2020.v05i01.003

\begin{abstract}
Beauty has always been a favorite of every woman to be more charming and confident. In fact, each region has a different understanding and standard of beauty. To look beautiful, many ways can be done by women. One of them is to use cosmetics. Cosmetics have existed since time immemorial, but over time, cosmetics have increasingly developed so that they have many different types, especially in Indonesia. Not only cosmetics in general, but also recently Indonesia has been hit with halal cosmetics. This is the right thing for companies to hook the market in Indonesia because Indonesian people are predominantly Muslim. So that makes people aware of the importance of halal cosmetic products in the market.

This study aimed to analyze the effect of Knowledge, Brand Ambassador Religiosity, Subjective Norm, Product Quality and Advertising on Repurchase Intention through Attitude towards Halal Cosmetic Products Wardah Cosmetics Customers in Surabaya. In this study the sample used was Wardah users who shopped within 3 months and had been using Wardah products for the past 6 months, having seen advertisements with Brand Ambassador Dewi Sandra and aged 18-60 years. This study uses 120 respondents and SPSS 22 to process data.
\end{abstract}

Keywords: Knowledge, Brand Ambassador Religiosity, Subjective Norm, Product Quality, Advertising, Attitude towards Halal Cosmetic Products, Repurchase Intention

\section{INTRODUCTION}




\section{International Journal of Social Science and Economic Research}

ISSN: $2455-8834$

Volume: 05, Issue: 01 "January 2020"

\subsection{Background of the Problem}

Beauty is one thing that every woman has and is the most beautiful gift for women. Beauty also requires a treatment. Beauty treatments began in ancient times where the Greeks believed that crocodile dung could slow the aging process. Then enter the medieval period where women are willing to cut themselves to the point of bleeding to make skin appear whiter. Then in the Renaissance era where makeup was recognized as capable of bewitching men so they were helpless by using leeches to drain blood from a woman's face to make her look pale and attractive. Then in the Elizabeth era where British women used egg whites to make their skin look glazed and dye their hair using alkaline even given oil made from lard. The last period is the modern era where many companies or organizations have created treatments for beauty in a form that is safer to use or consume. Basically the definition of beauty has different meanings in each region that are adjusted to the opinions and culture of each region. According to Wolf (2004), beautiful criteria can be seen from changes over time. Not only in general terms but beauty also has another view in an Islamic perspective where beauty is divided into physical beauty and physical beauty. Physical beauty is the beauty of a woman's outer appearance, jewelery or clothing that covers her body as required by Islam. While spiritual beauty or can be said to be the beauty of inner beauty which is more important for every woman as in the word of God which says "It is not lawful for you to marry women afterwards and may not (also) replace them with (other) wives, although her beauty attracts you except the women (slaves) that you have.

A woman's beauty in using make up makes the cosmetics industry grow rapidly and continue to innovate to meet the needs and desires of women in growing self-confidence. The development of the cosmetics industry in Indonesia itself is also very rapid with a variety of beauty trends that affect consumer patterns in Indonesia where the industry growth reached 9\% in 2019 compared to 2018 which was only $7.3 \%$. The growth of halal cosmetics has a high market demand in the Indonesian market which is supported by the majority of Indonesian people who are dominated by Muslims where not only food and drinks have a halal label but so do cosmetics used daily. Increasingly here, Indonesian people recognize the importance of using halal beauty products made from safe raw materials. Halal industry growth increased by $7.5 \%$ in 2015 to more than $8 \%$ in 2016 and continues to increase in 2017 and beyond. Halal cosmetics have reached around 11\% of the global market.

\subsection{Research Limits}

The limitations in this study are as follows: 
International Journal of Social Science and Economic Research

ISSN: 2455-8834

Volume: 05, Issue: 01 "January 2020"

1. This research examines Knowledge, Bramd Ambassador Religiosity, Subjective Norms, Product Quality, Advertising that affect Repurchase Intention through Attitude towards Halal Cosmetic Products

2. Testing of the studied model uses data from the results of the distribution of questionnaires on the object under study

3. Characteristics of the respondents examined as follows: respondents who live in Surabaya. Respondents have bought and used Wardah products in the past three months and routinely used them in the past six months. Respondents have seen Wardah advertisements with brand ambassador Dewi Sandra. Respondents have income $<500,000$ to> 3,800,001. Respondents are women who have 18-60 years of age (Kotler \& Armstrong, 2010).

\subsection{Problem Formulation}

The problems in the research are the factors that influence the Repurchase Intention of the Wardah brand in Surabaya, then to answer the questions in the research the following research questions will be used:

1. Does Knowledge have a significant effect on Attitude towards Halal Cosmetic Products for Wardah cosmetics consumers in Surabaya?

2. Does Brand Ambassador Religiosity significantly influence Attitude towards Halal Cosmetic Products for Wardah cosmetics consumers in Surabaya?

3. Does Subjective Norm have a significant effect on Attitude towards Halal Cosmetic Products for Wardah brand consumers in Surabaya?

4. Does Product Quality significantly influence Attitude towards Halal Cosmetic Products Products for Wardah brand consumers in Surabaya?

5. Does Advertising have a significant effect on Attitude towards Halal Cosmetic Products Products for Wardah brand consumers in Surabaya?

6. Does Attitude towards Halal Cosmetic Products significantly influence Wardah brand Repurchase Intention in Surabaya?

\section{LITERATURE REVIEW}

\subsection{Knowledge (KN)}

Ab Rahman (2015), refers to feelings or experiences known by a person or group of people. It can also be defined as awareness, familiarity gained through experience or learning. Knowledge has an influence on intention through attitude towards products. An increase in knowledge will affect intention (Bang, et al., 2000). There is an influential relationship between knowledge with 
International Journal of Social Science and Economic Research

ISSN: $2455-8834$

Volume: 05, Issue: 01 "January 2020"

attitudes towards products (Hamdan, et al., 2013). Knowledge refers to the cognitive elements associated with perception, memory and predictions that affect the responsiveness of consumers towards an object based on the value obtained (Bohner and Wanke, 2002). Knowledge with attitude can directly have a relationship that can be seen from the consistency and understanding of the attitude of every human being (Heimlich and Arrdoin, 2008).

H1: Knowledge has a significant effect on Attitude towards Halal Cosmetic Products for Wardah cosmetics consumers in Surabaya

\subsection{Brand Ambassador Religiosity (BAR)}

Religiosity covers a person's overall beliefs related to his religion, giving rise to attitudes that are in accordance with religious law (Glock 1972). Religiosity refers to one's attitude towards products regarding truth that is in accordance with religious teachings (Moschis and Ong, 2011). And religiosity is fundamental to determine attitude towards products (Nature, et al., 2011). Religiosity refers to the importance of a belief and how everything that is done can affect attitudes towards human products during life in the world (Briliana and Mursito, 2017). Religiosity involves emotional existence in which every thing produced can be either good or not good depending on the attitude towards each person's product (Rahman, et al., 2011). Every experience that someone feels will cause a more mature way of thinking that will affect attitude towards products (Johnson, 2001).

H2: Brand Ambassador Religiosity has a significant effect on Attitude towards Halal Cosmetic Products for Wardah cosmetics consumers in Surabaya

\subsection{Subjective Norm (SN)}

Subjective Norm can be interpreted one's attitude towards halal products and religiosity and subjective norms on attitude towards products towards halal cosmetic products and intention to buy halal products (Briliana and Mursito, 2017). Consumers tend to follow the recommended information from the surrounding environment such as friends, family and so on (Sulaiman, 2016). It can be said that references to the surrounding environment can decide the attitude towards products in making the decision to purchase (Ott, et al., 2003). Subjective norms are determined by the behavior that forms a consumer's attitude toward certain objects (Mowen, 2002). Once the subjective norm influences attitudes and shapes a perception it will make buying behavior more considered (Jogiyanto, 2015).

H3: Subjective Norm has a significant effect on Attitude towards Halal Cosmetic Products for Wardah cosmetics consumers in Surabaya 
International Journal of Social Science and Economic Research

ISSN: 2455-8834

Volume: 05, Issue: 01 "January 2020"

\subsection{Product Quality (PQ)}

Product Quality can be interpreted as the quality of a product that has an influence which is a dominant factor in influencing attitude towards product (Aynadis, 2014). The existence of good product quality will certainly have an impact on the attitudes of every consumer when making a purchase that is adjusted to the sales volume (Sirfaz, et al., 2014). The relationship between the quality of the product and the attitude of consumers in making purchases can run simultaneously or in part (Iranita, 2010).

H4: Product Quality has a significant effect on Attitude towards Halal Cosmetic Products for Wardah cosmetics consumers in Surabaya

\subsection{Advertising (AD)}

Advertising can be interpreted as a form of indirect communication where in general advertising can affect consumers' attitudes effectively (Mehta, 2000). Not only effective consumer attitudes but also the impact of the role of advertising itself on consumer attitudes (Greyser, 1972). The attitude of consumers in an advertisement is very significant so it is important when an advertisement can be delivered properly (Thorson, 1981). Advertising can show the existence of commercial preferences with consumer attitudes such as sales predictions resulting from these advertisements (Haley and Baldinger, 1991).

H5: Advertising has a significant effect on Attitude towards Halal Cosmetic Products for Wardah cosmetics consumers in Surabaya

\subsection{Repurchase Intention (RI) Attitude towards Halal Cosmetic Products (ATH)}

The stronger the attitude of a person and the stronger the intention to buy or consume, then it will be seen how a person can determine behavior to make a purchase decision so as to form a repurchase intention that reflects the hope of repurchasing the same product or brand (Briliana and Mursito, 2017). The desire of someone in choosing a product or service can be seen from the level of individual satisfaction resulting in a repurchase intention towards a brand (Filieri and Lin, 2017). Also the existence of environmental references that cause attitudes towards products in a brand can create repurchase intention (Seva, et al., 2007).

H6: Attitude towards Halal Cosmetic Products has a significant effect on Purchase Intention of Wardah cosmetics consumers in Surabaya

\section{RESEARCH METHODOLOGY}

\subsection{Types of Research}


This type of research is causal research because this research is used to explain the causal relationship between variables (Zikmud, 2009: 16). The research model consisted of Repurchase Intention, Attitude towards Halal Cosmetic Products, Knowledge, Brand Ambassador Religiosity, Subjective Norms, Product Quality and Advertising. This research uses quantitative methods that are based on numerical information that is associated with numerical analysis. This study aims to find facts to draw a causal conclusion between the variables used.

\subsection{Population and Sample}

Population is a generalization area that consists of objects or subjects that have certain quantities and characteristics determined by researchers to be examined and then drawn a conclusion (Sugiyono, 2002). The population used in this study is Wardah brand consumers in Surabaya. The population used is customers who have or are currently using Wardah.

The sample is part of the population that is expected to be able to represent the population in a study (Zikmund, 2009: 68). Sugiyono (2002) also states that a sample of 120 respondents. The sampling technique used in this study was purposive sampling. The area used as the place for distributing questionnaires was the Surabaya city area.

\subsection{Data Collection Methods}

The level used in this study is the level of interval measurement using a Likert Scale type. The scale used in this research questionnaire uses a scale of 1-5 with the following values:
1. Strongly disagree
2. Disagree
3. Neutral

4. Agree

5. Strongly agree

\begin{tabular}{|c|c|c|}
\hline Variable & Measurement & $\begin{array}{c}\text { Statement } \\
\text { Scale }\end{array}$ \\
\hline Knowledge & $\begin{array}{l}\text { 1. Wardah provides adequate information regarding the halal } \\
\text { label given on the package } \\
\text { 2. Wardah is able to communicate the quality of the product } \\
\text { well } \\
\text { 3. Wardah is able to provide information about product } \\
\text { innovation compared to competitors }\end{array}$ & $\begin{array}{c}\text { Scale of } 5 \\
\text { Points }\end{array}$ \\
\hline $\begin{array}{c}\text { Brand } \\
\text { Ambassador } \\
\text { Religiosity }\end{array}$ & $\begin{array}{l}\text { 1.Brand Ambassador Wardah regularly follows Islamic } \\
\text { studies } \\
\text { 2.Brand Ambassador Wardah always tries to help people } \\
\text { who need help } \\
\text { 3.Brand Ambassador Wardah always tries to behave } \\
\text { honestly }\end{array}$ & $\begin{array}{c}\text { Scale of } 5 \\
\text { Points }\end{array}$ \\
\hline
\end{tabular}


International Journal of Social Science and Economic Research

ISSN: 2455-8834

Volume: 05, Issue: 01 "January 2020"

\begin{tabular}{|c|c|c|}
\hline $\begin{array}{c}\text { Subjective } \\
\text { Norm }\end{array}$ & $\begin{array}{l}\text { 1.I feel that the people I consider important in my life } \\
\text { choose to use Wardah Cosmetics, which are halal } \\
\text { products } \\
\text { 2.I feel that my family chose to use Wardah Cosmetics, } \\
\text { which is a halal product } \\
\text { 3.I feel that my friends choose to use Wardah Cosmetics, } \\
\text { which are halal products }\end{array}$ & $\begin{array}{c}\text { Scale of } 5 \\
\text { Points }\end{array}$ \\
\hline $\begin{array}{l}\text { Product } \\
\text { Quality }\end{array}$ & $\begin{array}{l}\text { 1.I feel Wardah Cosmetics has good product quality } \\
\text { 2.I feel Wardah Cosmetics is a product that suits consumers' } \\
\text { needs } \\
\text { 3.I feel Wardah Cosmetics has good product durability } \\
\text { 4.I feel Wardah Cosmetics has a wide selection of quality } \\
\text { products }\end{array}$ & $\begin{array}{c}\text { Scale of } 5 \\
\text { Points }\end{array}$ \\
\hline Advertising & $\begin{array}{l}\text { 1.I feel Wardah Cosmetics ads are useful in informing about } \\
\text { products } \\
\text { 2.I feel that Wardah Cosmetics ads provide interesting } \\
\text { product information compared to other similar products } \\
\text { 3.I feel Wardah Cosmetics ads are creative in delivering } \\
\text { their products }\end{array}$ & $\begin{array}{c}\text { Scale of } 5 \\
\text { Points }\end{array}$ \\
\hline $\begin{array}{c}\text { Attitude } \\
\text { Towards } \\
\text { Halal } \\
\text { Cosmetic } \\
\text { Products }\end{array}$ & $\begin{array}{l}\text { 1.I am happy about Wardah Cosmetics, which is a halal } \\
\text { product } \\
\text { 2.I always look for halal labels when buying Wardah } \\
\text { Cosmetics products } \\
\text { 3.I feel it is important to use halal products such as Wardah } \\
\text { Cosmetics }\end{array}$ & $\begin{array}{c}\text { Scale of } 5 \\
\text { Points }\end{array}$ \\
\hline $\begin{array}{l}\text { Repurchase } \\
\text { Intention }\end{array}$ & $\begin{array}{l}\text { 1.I will go back to buy Wardah Cosmetics in the future } \\
\text { 2. When I think of buying Cosmetics, my first choice is to } \\
\text { keep buying Wardah Cosmetics } \\
\text { 3. When Wardah Cosmetics releases a new product, I will } \\
\text { buy the new product }\end{array}$ & $\begin{array}{c}\text { Scale of } 5 \\
\text { Points }\end{array}$ \\
\hline
\end{tabular}

\section{DATA ANALYSIS AND DISCUSSION}

Most of Wardah's cosmetics users in Surabaya have a percentage of $100 \%$ where respondents have a vulnerable age between 18-35 years with a large income of $21.7 \%$ of Rp. 1,000,001 - Rp. $2,000,000,74.2 \%$ in the amount of Rp. 2,000,001 - Rp 3,800,000 and 4.1\% of> Rp. 3,800,001.

Results of the Determination Coefficient Analysis 1 (R2)

\begin{tabular}{|c|c|}
\hline Variable & Adjusted R $^{2}$ \\
\hline KN,BAR,SN,PQ,AD*ATH & 0.745 \\
\hline
\end{tabular}

Based on the output, the R2 value is 0.745 or $74.5 \%$. This shows that the percentage of contribution of leadership influence of independent variables (independent) Knowledge (KN), 
Brand Ambassador (BAR), Subjective Norm (SN), Product Quality (PQ) and Advertising (AD) on the dependent variable (dependent) Attitude towards Halal Cosmetic Products (ATH) by $74.5 \%$. This means that the independent variable is able to explain at $74.5 \%$ the dependent variable, while the remaining $25.5 \%$ is influenced by other variables not included in this research model.

Results of the Determination Coefficient Analysis 2 (R2)

\begin{tabular}{|c|c|}
\hline Variable & Adjusted $\mathbf{R}^{\mathbf{2}}$ \\
\hline $\mathrm{ATH} * \mathrm{RI}$ & 0.319 \\
\hline
\end{tabular}

Based on the output, R2 is 0.319 or $31.9 \%$. This shows that the percentage contribution of the independent variable (independent) Attitude towards Halal Cosmetic Products (ATH) to the dependent variable Repurchase Intention (RI) was $31.9 \%$. This means that the independent variable is able to explain at $31.9 \%$ the dependent variable, while the remaining $68.1 \%$ is influenced by other variables not included in this research model.

\section{Simultaneous Significance Test (F-Test)}

If the significance is $>0.05$, the hypothesis is rejected.

If the significance is $\leq 0.05$, the hypothesis is accepted

\begin{tabular}{|c|c|c|c|}
\hline Variable & Sig. & Standart & \\
\hline KN,BAR,SN,PQ,AD*ATH & 0.00 & 0.05 & Hypothesis accepted \\
\hline ATH *RI & 0.00 & 0.05 & Hypothesis accepted \\
\hline
\end{tabular}

Based on the ANOVA test or the F test in the table above, the significance obtained (KN, BAR, $\mathrm{SN}, \mathrm{PQ}, \mathrm{AD} * \mathrm{ATH})$ is 0.00 . Based on the hypothesis testing criteria if the significance $\leq 0.05$, the hypothesis is accepted, meaning Knowledge (KN), Brand Ambassador (BAR), Subjective Norm (SN), Product Quality (PQ) and Advertising (AD) simultaneously have a significant effect on Attitude towards Halal Cosmetic Products (ATH).

Based on the ANOVA test or the F test in the above table, the significance (ATH * RI) obtained is 0.00 . Based on the hypothesis testing criteria if the significance $\leq 0.05$, the hypothesis is accepted, meaning that Attitude towards Halal Cosmetic Products (ATH) simultaneously has a significant effect on Repurchase Intention (RI).

Partial Significance Test (T-test)

\begin{tabular}{|c|c|c|c|}
\hline Variabel & Sig & Standart & Keterangan \\
\hline $\mathrm{KN} * \mathrm{ATH}$ & 0.542 & 0.05 & Hypothesis rejected \\
\hline
\end{tabular}


International Journal of Social Science and Economic Research

ISSN: 2455-8834

Volume: 05, Issue: 01 "January 2020"

\begin{tabular}{|c|c|c|c|}
\hline BAR *ATH & 0.039 & 0.05 & Hypothesis accepted \\
\hline SN *ATH & 0.000 & 0.05 & Hypothesis accepted \\
\hline PQ *ATH & 0.000 & 0.05 & Hypothesis accepted \\
\hline AD *ATH & 0.006 & 0.05 & Hypothesis accepted \\
\hline ATH *RI & 0.000 & 0.05 & Hypothesis accepted \\
\hline
\end{tabular}

If the significance is $>0.05$, the hypothesis is rejected.

If the significance is $\leq 0.05$, the hypothesis is accepted.

Based on the table above it can be seen that:

1. Knowledge Variable (KN)

The significance value of the $\mathrm{KN}$ variable is 0.542 the standard value is 0.05 . Then the significance of <standard $(0.001<0.05)$ so that it can be concluded that the $\mathrm{KN}$ variable has no effect $(0<0.05)$ individually to Attitude towards Wardah Halal Cosmetic Products in Surabaya.

2. Variable Brand Ambassador Religiosity (BAR)

The significance value of the BAR variable is 0.039 the standard value is 0.05 . Then the significance of <standard $(0.039<0.05)$ so that it can be concluded that the BAR variable influences $(0<0.05)$ individually to Attitude towards Wardah Halal Cosmetic Products in Surabaya.

\section{Subjectve Norm (SN) Variable}

The significance value of the $\mathrm{SN}$ variable is 0,000 the standard value is 0.05 . So the significance of < standard $(0.000<0.05)$ so that it can be concluded that the $\mathrm{SN}$ variable influences $(0<0.05)$ individually to Attitude towards Wardah Halal Cosmetic Products in Surabaya.

\section{Product Quality (PQ) Variable}

The significance value of the PQ variable is 0,000 the standard value is 0.05 . So the significance of < standard $(0.000<0.05)$ so that it can be concluded that the MVr variable influences $(0<0.05)$ individually to Attitude towards Wardah Halal Cosmetic Products in Surabaya.

5. Variable Advertising (AD)

The significance value of the $\mathrm{AD}$ variable is 0.006 the standard value is 0.05 . So the significance of $>$ standards $(0.006<0.05)$ so that it can be concluded that the AD variable has no effect $(0$ $<0.05)$ individually to Attitude towards Wardah Halal Cosmetic Products in Surabaya.

6. Variable Attitude towards Halal Cosmetic Products (ATH) 
International Journal of Social Science and Economic Research

ISSN: $2455-8834$

Volume: 05, Issue: 01 "January 2020"

The significance value of the ATH variable is 0,000 the standard value is 0.05 . Then the significance of <standard $(0.000<0.05)$ so that it can be concluded that the ATH variable influences $(0<0.05)$ individually to Wardah Cosmetic Repurchase Intention in Surabaya

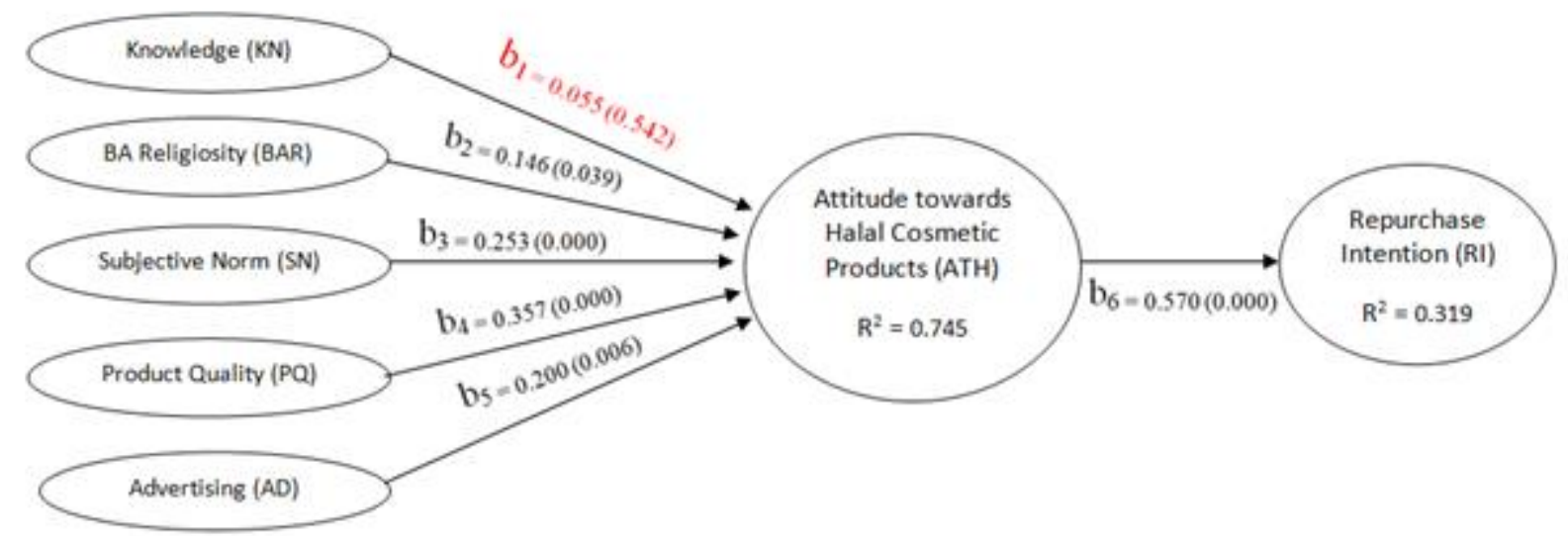

\section{CONCLUSIONS, IMPLICATIONS AND RECOMMENDATIONS}

Knowledge variables that influence Attitude towards Halal Cosmetic Products are formed by indicators that state that knowledge about the halal products is good, able to communicate product quality well and provide better product innovation compared to other competitors in Surabaya. Whereas Attitude towards Halal Cosmetic Products is formed by indicators that customers will be happy when using Wardah products, always prioritizing halal labels and the importance of using halal cosmetics such as Wardah cosmetics. towards Halal Cosmetic Products.

The Brand Ambassador Religiosity variable that affects Attitute towards Halal Cosmetic Products is formed by indicators of BA money following Islamic studies, BA always helps people who need help and always behaves honestly. Whereas Attitude towards Halal Cosmetic Products is formed by indicators that customers will be happy when using Wardah products, always prioritizing halal labels and the importance of using halal cosmetics such as Wardah cosmetics.

Subjective Norm variables that influence Attitude towards Halal Cosmetic Porducts are formed by indicators that people who are considered important in their lives will encourage to use the halah products owned by Wardah, family influence in using Wardah halal products and the influence of friends in using Wardah halal products. Whereas Attitude towards Halal Cosmetic Products is formed by indicators that customers will be happy when using Wardah products, 


\section{International Journal of Social Science and Economic Research}

ISSN: $2455-8834$

Volume: 05, Issue: 01 "January 2020"

always prioritizing halal labels and the importance of using halal cosmetics such as Wardah cosmetics.

Product Quality Variables that influence Attitude towards Halal Cosmetic Porducts are formed by indicators that Wardah has good product quality, products that fit consumer needs, has good durability and has a wide selection of quality products. Whereas Attitude towards Halal Cosmetic Products is formed by indicators that customers will be happy when using Wardah products, always prioritizing halal labels and the importance of using halal cosmetics such as Wardah cosmetics.

Advertising variables that influence Attitude towards Halal Cosmetic Porducts formed by Wardah advertising indicators are useful in informing their products, the information conveyed is different from its competitors and creative in delivering its products. Whereas Attitude towards Halal Cosmetic Products is formed by indicators that customers will be happy when using Wardah products, always prioritizing halal labels and the importance of using halal cosmetics such as Wardah cosmetics.

The Attitude towards Halal Cosmetic Product is formed by indicators that customers will be happy when using Wardah products, always prioritizing halal labels and the importance of using halal cosmetics such as Wardah cosmetics. While the Repurchase Intention variable is formed by indicators the customer will buy Wardah products again in the future, Wardah will be the first choice product and will buy new products from Wardah.

Through research that has been conducted on 120 respondents with an age range between 18-60 years and based on literature review conducted, it is obtained significant support that Attitude towards Halal Cosmetic Products with a regression coefficient of 0.570. While Knowledge has no significant effect on Attitude towards Halal Cosmetic Products with a regression coefficient of 0.055, Brand Ambassador Religiosity has a significant effect on Attitude towards Halal Cosmetic Products with a regression coefficient of 0.146, Subjective Norm has a significant effect on Attitude towards Halal Cosmetic Products with a regression coefficient of 0.253, Product Quality has a significant effect on Attitude towards Halal Cosmetic Products with a regression coefficient of 0.357 and Advertising has a significant effect on Attitude towards Halal Cosmetic Products with a regression coefficient of 0.200 . 


\section{International Journal of Social Science and Economic Research}

ISSN: $2455-8834$

Volume: 05, Issue: 01 "January 2020"

\section{IMPLICATIONS}

\section{Theoritical Implications}

\begin{tabular}{|c|c|c|}
\hline Penelitian Terdahulu & Penelitian Sekarang & Implikasi Teoritis \\
\hline $\begin{array}{l}\text { Bang, et al (2000), Knowledge } \\
\text { has an influence on intention } \\
\text { through attitude towards products. } \\
\text { An increase in knowledge will } \\
\text { affect intention }\end{array}$ & $\begin{array}{l}\text { Knowledge from Wardah } \\
\text { cosmetics customers in Surabaya } \\
\text { does not significantly influence } \\
\text { Attitude towards Halal Cosmetic } \\
\text { Products }\end{array}$ & $\begin{array}{l}\text { Supporting and strengthening } \\
\text { Saaksjarvi, et al (2009) said that } \\
\text { there was no significant effect } \\
\text { between knowledge variables on } \\
\text { attitude }\end{array}$ \\
\hline $\begin{array}{l}\text { In the research of Moschis and } \\
\text { Ong (2011) states Religiosity } \\
\text { refers to the attitude towards one's } \\
\text { products regarding the truth in } \\
\text { accordance with the teachings of } \\
\text { religion. }\end{array}$ & $\begin{array}{l}\text { Brand Ambassador Religiosity } \\
\text { from Wardah cosmetics customers } \\
\text { in Surabaya has a significant } \\
\text { effect on Attitude towards Halal } \\
\text { Cosmetic Products }\end{array}$ & $\begin{array}{l}\text { Support and strengthen Moschis } \\
\text { and Ong (2011) which states that } \\
\text { Religiosity refers to one's attitude } \\
\text { towards products regarding truth } \\
\text { that is in accordance with } \\
\text { religious teachings. }\end{array}$ \\
\hline $\begin{array}{l}\text { In the study of Briliana and } \\
\text { Mursito (2017) states Subjective } \\
\text { Norm can be interpreted a } \\
\text { person's attitude towards halal } \\
\text { products and religiosity and } \\
\text { subjective norms on attitude } \\
\text { towards products towards halal } \\
\text { cosmetic products and intention to } \\
\text { buy halal products }\end{array}$ & $\begin{array}{l}\text { Subjective Norm of Wardah } \\
\text { cosmetics customers in Surabaya } \\
\text { has a significant effect on Attitude } \\
\text { towards Halal Cosmetic Products }\end{array}$ & $\begin{array}{l}\text { Supporting and strengthening } \\
\text { Briliana and Mursito (2017) } \\
\text { which states that Subjective Norm } \\
\text { can be interpreted as a person's } \\
\text { attitude towards halal products } \\
\text { and religiosity and subjective } \\
\text { norms on attitudes }\end{array}$ \\
\hline $\begin{array}{l}\text { In the study of Aynadis (2014) } \\
\text { states Product Quality can be } \\
\text { interpreted the quality of a } \\
\text { product that has an influence } \\
\text { which is a dominant factor in } \\
\text { influencing attitude towards } \\
\text { product }\end{array}$ & $\begin{array}{l}\text { Product Quality from Wardah } \\
\text { cosmetics customers in Surabaya } \\
\text { has a significant effect on Attitude } \\
\text { towards Halal Cosmetic Products }\end{array}$ & $\begin{array}{l}\text { Supporting and strengthening } \\
\text { Aynadis (2014) which states } \\
\text { Product Quality can be interpreted } \\
\text { as the quality of a product that has } \\
\text { an influence which is a dominant } \\
\text { factor in influencing attitude } \\
\text { towards product }\end{array}$ \\
\hline $\begin{array}{l}\text { In the research of Haley and } \\
\text { Baldinger (1991) states } \\
\text { advertising can show the existence } \\
\text { of commercial preferences with } \\
\text { consumer attitudes such as sales } \\
\text { predictions resulting from these } \\
\text { advertisements }\end{array}$ & $\begin{array}{l}\text { Advertising from Wardah } \\
\text { cosmetics customers in Surabaya } \\
\text { has a significant effect on Attitude } \\
\text { towards Halal Cosmetic Products }\end{array}$ & $\begin{array}{l}\text { Support and strengthen Haley and } \\
\text { Baldinger (1991) who state that } \\
\text { advertising can show a } \\
\text { commercial preference for } \\
\text { consumer attitudes such as sales } \\
\text { predictions resulting from these } \\
\text { advertisements }\end{array}$ \\
\hline $\begin{array}{l}\text { In the study of Seva, et al (2007) } \\
\text { states that there is a reference to } \\
\text { the surrounding environment that } \\
\text { causes attitude towards products } \\
\text { in a brand can create repurchase }\end{array}$ & $\begin{array}{l}\text { Attitude towards Halal Cosmetic } \\
\text { Products from Wardah cosmetics } \\
\text { customers in Surabaya has a } \\
\text { significant effect on Repurchase }\end{array}$ & $\begin{array}{l}\text { Supporting and strengthening } \\
\text { Seva, et al (2007) which states } \\
\text { that there is a reference to the } \\
\text { surrounding environment that } \\
\text { causes attitude towards products }\end{array}$ \\
\hline
\end{tabular}




\section{International Journal of Social Science and Economic Research}

ISSN: $2455-8834$

Volume: 05, Issue: 01 "January 2020"

\begin{tabular}{|l|l|l|}
\hline intention & Intention & $\begin{array}{l}\text { in a brand can create repurchase } \\
\text { intention }\end{array}$ \\
\hline
\end{tabular}

\section{Manajerial Implications}

\begin{tabular}{|l|}
\hline \multicolumn{1}{|c|}{ Penelitian Sekarang } \\
\hline Knowledge can refer to facts, feelings or experiences \\
that are known by a person or group of people. It can \\
also be defined as an awareness or familiarity gained \\
with experience or learning (Rahman, 2015).
\end{tabular}

Brand ambassadors are tools used by companies to communicate public relations, with the hope that they can increase sales volume (Greenwood, 2012).
Subjective Norm is a function of a belief which can determine an individual's thoughts regarding certain behaviors by the group concerned as well as when consuming halal products Pepper and Amin, 2009)
1. Wardah needs to improve quality such as changing ingredients and informing further that there is a new formula so that the information can be conveyed well to customers.

2. Wardah should train her team more to be able to communicate their products, especially for new products with the help of counter guards. And pay more attention and educate his team well.

3. Wardah must continue to improve customer information about product innovation compared to competitors, for example by increasing brand image

1. It is necessary for Wardah to always pay attention to BA's attitude, choose BA like Laudya Chyntia Bella to convey good things and bring good to the environment and have a BA who has an interesting life story that supports Wardah's journey going forward.

2. Wardah is able to collaborate with BA to create an exclusive veil of Wardah $x$ Laudya Chyntia Bella where when a customer purchases a new product with a minimum purchase of Rp. 500,000 will get an exclusive veil.

3. Wardah must always carry out social activities outside of the month of Ramadan, so as to reflect the sincerity of the role of BA in doing good by helping people who need help.

1. It is important for Wardah to maintain public figures ranging in age between 18-35 years because they are considered successful in influencing customers to use their products. Because many customers are also affected by public figures who have been considered as trendsetters for every product used.

2. It is necessary for Wardah to reach the adult and adolescent markets by increasing the shade of colors on products such as eyeshadow and cushion which do not yet have too many colors that can be used to better support recommendations between families who have further age differences.

3. Wardah needs to improve products that meet the needs of consumers so that it reaches many people 


\section{International Journal of Social Science and Economic Research}

ISSN: $2455-8834$

Volume: 05, Issue: 01 "January 2020"

\begin{tabular}{|c|c|}
\hline & $\begin{array}{l}\text { with different age ranges and incomes so that more } \\
\text { and more customers use the product and make it } \\
\text { easier for customers to find a lot of information } \\
\text { about Wardah products from the friendship } \\
\text { environment. Because usually the influence of the } \\
\text { friendship environment tends to be easily accepted } \\
\text { from one another. }\end{array}$ \\
\hline $\begin{array}{l}\text { Product Quality is the overall goods and services } \\
\text { related to the desires of consumers who are superior } \\
\text { products are sold according to the expectations of } \\
\text { customers (Kotler and Armstrong, 2008) }\end{array}$ & $\begin{array}{l}\text { 1. Wardah needs to improve the stability of the } \\
\text { quality and color of the product to remain consistent } \\
\text { because sometimes even though the shade of the } \\
\text { product is the same, the color can be different so that } \\
\text { Wardah needs further attention. } \\
\text { 2. Wardah needs to improve its products to always } \\
\text { meet women's needs regarding halal cosmetics that } \\
\text { are safe, affordable and have many choices for skin } \\
\text { types and skin colors of cosmetics customers in } \\
\text { Indonesia. Wardah also makes spray-like products to } \\
\text { refresh the face or skin of women in undergoing their } \\
\text { activities without the need to wash their face and } \\
\text { remove their makeup. } \\
\text { 3. Wardah needs to pay close attention to lipcream } \\
\text { products when each color has the same durability. } \\
\text { The consistency of different shade pigmentation } \\
\text { sometimes also causes different pigmentation, some } \\
\text { are longlast and some are easily lost. This can be an } \\
\text { input and improvement for Wardah in the future. } \\
\text { 4. It is necessary for Wardah to use the right } \\
\text { composition so that it is not easily lost or transferred } \\
\text { and contains too much oxidized from the customer's } \\
\text { skin. And always maintain a stable quality in every } \\
\text { product so that when all the different products are } \\
\text { applied to the face it can be seen to blend perfectly }\end{array}$ \\
\hline $\begin{array}{l}\text { Advertising is a form of indirect communication, } \\
\text { which is based on information about the benefits, or } \\
\text { excellence of a product, arranged in such a way as to } \\
\text { cause a sense of fun that will change someone's mind } \\
\text { to make a purchase (Tjiptono, 2012). }\end{array}$ & $\begin{array}{l}\text { 1. It is necessary for Wardah to add variations } \\
\text { Wardah is expected to better improve creativity in } \\
\text { delivering or promoting its advertisements, one way } \\
\text { is to hold a gathering that invites many public figures } \\
\text { where at the event each participant is required to use } \\
\text { all types of Wardah cosmetics and then hold a kind } \\
\text { of competition both indoor and outdoor to prove the } \\
\text { durability of its products. } \\
\text { 2. Wardah needs to provide interesting product } \\
\text { information such as when introducing new Alovera } \\
\text { products that use public figures who are using their } \\
\text { products in all conditions which contain rich } \\
\text { properties that can enhance the appearance and } \\
\text { nourish the skin. So that every customer who uses } \\
\text { has high self-confidence and is not anxious when } \\
\text { using the product. Providing innovations in both } \\
\text { color games and providing unique mascots to } \\
\text { promote their products. }\end{array}$ \\
\hline
\end{tabular}




\section{International Journal of Social Science and Economic Research}

ISSN: $2455-8834$

Volume: 05, Issue: 01 "January 2020"

Attitude towards Halal Cosmetic Products is defined as all marketing related activities that can influence consumer attitudes (Schiffman and Kanuk, 2007).
Repurchase Intention is a person's planned decision to make repeated purchases of certain services, taking into account the situation and the level of customer satisfaction (Hellier, et al., 2003).
3. Wardah needs to add ad models by using models that have different skin tones, namely skin tones that tend to be dark so customers have a clear and suitable use of colors or shades that can be used on customers who have dark skin tones

1. Wardah needs to maintain and improve quality that is already good in the eyes of consumers and improve the ingredients of products that are considered disappointing by many customers. Not only quality, but customers like to use Wardah cosmetics because of the affordable prices of many people.

2. It is important for Wardah to always put the halal label on the banner, counter, product or product packaging. Even though Wardah is already famous for halal certification, with the clearer halal label, consumers will feel more confident when they buy and use the product.

3. Wardah must always maintain halal certification and use products that are safe for skin and health. Wardah is expected not to be careless in labeling halal on its products so that when there is an inspection in Wardah's production process, there are no parties disappointed especially for Wardah's customers themselves.

1. Wardah strives to always establish long-term relationships with its customers through programs such as giving discounts, providing mini games such as snakes and ladders to provide entertainment while remembering and maintaining the types of toys typical of Indonesia which have now begun to be replaced by gadgets that will win prizes from Wardah .

2. Wardah has the courage to guarantee that her products are of the highest quality at an affordable price by having various color alternatives according to the needs of skin color and weather / climate that are owned by Indonesian women in addition to the halal label which is also important for the majority of the Indonesian population.

3. Wardah can give gifts to customers who will buy new products, where pre-orders for special products are held so that not all customers can take advantage of the pre-order period where when participating in the program customers have advantages such as attending new product launches, getting a new set of cosmetics. compared to other customers, get a makeup pouch, get makeup tools 
International Journal of Social Science and Economic Research

ISSN: 2455-8834

Volume: 05, Issue: 01 "January 2020"

\section{RECOMMENDATION}

See the limitations regarding the object of research that only takes respondents, namely customers from Wardah cosmetic products in Surabaya. Further research is expected to be able to complete the variables that already exist in this study so that it can further refine the factors that influence Repuchase Intention, for example the variable Perceived Behavioral Control and so forth. Further research can be developed or broaden the scope of respondents in areas that are different from the current research. So that further research can be carried out that will increasingly provide a broader picture of Repurchase Intention.

\section{REFERENCES}

Afina Siti, Retnaningsih. 2018. The Influence of Students Knowledge and Attitude Toward Functional Foods Consumption Behavior. Journal of Consumer Sciences. Vol. 03, pp. 114.

Aghaei, Mohammad. 2016. Investigation of the Relationship between Religiosity and Controversial Product and Service Purchase. Journal of Humanities and Cultural Studies. (January).

Azwar, Azrul. 1996. Menjaga Mutu Pelayanan Kesehatan. Jakarta: Pustaka Sinar Harapan.

Azwar. Widjaja. (2009). Perencanaan Sebagai Fungsi Manajemen. Jakarta: Penerbit PT. Rineka Cipta.

Bustanuddin Agus, Agama Dalam Kehidupan Manusia, (Jakarta: Raja Grafindo Persada, 2007).

Dodds, B., Monroe Kent B., dan Dhruv Grewal (1991), "Effect of Price, Brand,and Store Information on Buyers' Product Evaluations", Journal of Marketing Research, 28 (August), p.307-319)

Engel, Blackwell, Miniard. 2001. Consumer Behavior 9th Edition. Ohio: South Western.

Firmansyah, Febby. 2010. Analisis Pengaruh Tingkat Religiusitas Pasien Terhadap Keputusan Menggunakan Jasa Kesehatan (Studi Pada Pasien PKU Muhammadiyah Roemani Semarang). Jurnal. Semarang: Perpustakaan Fakultas Ekonomi Universitas Diponegoro.

Glock, C. \& Stark, R. 1966. Religion and Society In Tension. Chicago: University of California.

Gunarsa. Singgih dan Ny. SD. Gunarsa. 1991. Psikologi Praktis Anak Remaja dan Keluarga. Jakarta: BPK Gunung Mulia. 


\section{International Journal of Social Science and Economic Research}

ISSN: $2455-8834$

Volume: 05, Issue: 01 "January 2020"

Hair, et al. (2006). Multivariate Data Analysis, $5^{\text {th }}$ Edition. New Jersey: Pearson Education.

Hair, J. F. et al. (1995). Multivariate Data Analysis, $4^{\text {th }}$ Edition. New Jersey: Prentice Hall International Inc.

Hair, J. F. et al. (2007). Multivariate Data Analysis, 6th Edition. New Jersey: Pearson Education Inc.

Hellier, Philip K, Geursen Gus M, Carr Rodney A, and Rickard John A, 2003. Customer Repurchase Intention : A General Structural Equation Model, Journal Of Marketing, Vol.37, pp:1762-1800

Imam Ghozali. (2004). Aplikasi analisis Multivariate dengan Program SPSS. Semarang: Badan

Indika, Deru R dan Safia Lainufar. 2016. Eksplorasi Sikap Konsumen terhadap Kosmetik Halal (Studi Kasus: Wardah). Jurnal. Bandung: Universitas Padjajaran

Indrianawati, Usman dan rizky Adhitya Arnando. Pengaruh Promosi Penjualan terhadap Repurchase Melalui Trial Dengan Moderasi Fear Of Losing Face pada Sogo Department Store Surabaya. Fakultas Ekonomi Universitas Airlangga,(Surabaya : jurnal equitas vol.11 no.2 maret 2007), h.181

Kotler, Philip dan Keller, 2007, Manajemen Pemasaran, Jilid I, Edisi Kedua belas, PT. Indeks, Jakarta.

Korichi, Rodolph; Delphine Pelle De Queral; Germaine Gazano., et al. 2007. Why Women Use Make Up: Implication of Psychological Traits in Make Up Functions. Journal of Cosmetic Science, 59 (March/April): 127-137.

Mowen dan Minor. 1998. Perilaku Konsumen. Erlangga: Jakarta

Muhaimin. 2002. Paradigma Pendidikan Islam : Upaya Mengefektifkan Pendidikan Agama Sekolah. Bandung: Mahasiswa Rodakarya.

Pullias, Earl V and James D young. 2006. Teacher is many thing, USA. Fawcett.

Rahman Azmawi, et al,.2015. Consumer and Halal Cosmetic Products: Knowledge, Religiosity, Attitude adn Intention. Journal of Islamic Marketing, Vol. 6, pp. 148-163.

Respati, Widya Dian. 2017. Pengaruh Brand Ambassador, Brand Image Dan Kualitas Produk Terhadap Minat Beli Produk Lipstik Wardah. Jurnal. Jember: Universitas Muhammadiyah Jember. 
International Journal of Social Science and Economic Research

ISSN: 2455-8834

Volume: 05, Issue: 01 "January 2020"

Robustin, Tri Palupi dan Anisatul Fauziah. 2018. Pengaruh Kualitas Produk dan Word of Mouth terhadap Keputusan Pembelian Kosmetik Wardah pada Masyarakat di Kota Jember. Jurnal. Lumajang: STIE Widya Gama Lumajang

Roelof, Howard Dykema. 1929. The Experimental Method and Religious Beliefs. Journal of Mind Association, 38 (April): 184-206

Royan, Frans M. 2004. Marketing Selebrities. Jakarta: PT Elex Media Komputindo.

Samosir, Ligia Stephani; Yuliani Rachma Putri; Sylvie Nurfebiaraing. 2017. Pengaruh Penggunaan Brand Ambassador Dewi Sandra Terhadap Putusan Pembelian Kosmetik Wardah Di Kota Bandung. Jurnal. Bandung; Universitas Telkom.

Setyorini, Retno dan Gita, Devi. (2015). Pengaruh Brand Ambassador Terhadap Brand Image Perusahaan Online Zalora.co.id. Jurnal

Situmorang, Robinson. 2004. Strategi Pembelajaran Multiple Intelligences. Jakarta: Kencana.

Tung, Lo Choi. 2011. The Impact of Entrepreneurship Education on Entrepreneurial Intention of Engineering Students. City University of Hongkong: Run Run Show Library

Wahjono, Padmo, 1986, Indonesia Negara Berdasarkan Atas Hukum, Ghalia Indonesia, Jakarta.

Wolf, Naomi. 2004. Mitos Kecantikan; Kala Kecantikan Menindas Perempuan. Yogyakarta: Niagara.

https://www.academia.edu/9236371/Wardah?auto=download, diunduh pada tahun 2018

https://www.amazine.co/17414/sejarah-kecantikan-perawatan-kecantikan-yang-aneh-unik/, diunduh pada 2019

http://www.creation7thdayadventism.dk/ExperimentalReligion.html, diunduh pada 2017

https://gayahidup.republika.co.id/berita/plv4i8328/cara-wardah-hadirkan-produk-kosmetik-halal, diunduh pada 25 Januari 2019

https://id.priceprice.com/kecantikan/news/Mengenal-Wardah-dan-Produk-Kosmetik-Terbaiknya6044/, diunduh pada 23 Juli 2018)

https://industri.kontan.co.id/news/paragon-bidik-penjualan-2018-tumbuh-lebih-dari-30, diunduh pada 3 April 2019 
International Journal of Social Science and Economic Research

ISSN: 2455-8834

Volume: 05, Issue: 01 "January 2020"

http://karyailmiah.unisba.ac.id/index.php/mankom/article/view/12588, diunduh pada Agustus 2018

www.katadata.com diunduh pada 10 April 2019

https://kumparan.com/@kumparanstyle/daftar-kosmetik-halal-di-indonesia-yang-telahdisertifikasi-mui-1548333618812262658, diunduh pada 24 Januari 2014

https://lifestyle.kompas.com/read/2013/04/25/1313261/Dewi.Sandra..Duta.Kosmetik.Muslimah, diunduh pada 25 April 2013

www.marketers.com, diunduh pada 24 Mei 2017

http://www.neraca.co.id/article/63045/nurhayati-subakat-ceo-pt-paragon-technology-innovationjatuh-bangun-mengenalkan-kosmetik-halal, diunduh pada 7 Agustus 2019

https://www.researchgate.net/publication/315479677 pengaruh penggunaan brand ambassador dewi sandra terhadap putusan pembelian kosmetik wardah di kota bandung, diunduh pada 15 Februari 2016

www.republika.co.id diunduh pada 30 Maret 2019

https://www.republika.co.id/berita/ekonomi/korporasi/19/01/08/pl0tdr349-wardah-tumbuh-30persen-pada-2018, diunduh pada 10 Januari 2019

www.ubaya.ac.id diunduh pada 1 Desember 2010

https://www.youtube.com/watch?v=78leELEdGv4, diunduh pada 17 Mei 2013

https://www.youtube.com/watch?v=uwrOUNuEBj0, diunduh pada 26 Mei 2017 